\title{
Incidente em Antares $e$ os paradoxos da arte de representar
}

Maria Nazareth Soares Fonseca I PUC Minas

Resumo: O artigo pretende focalizar, no romance Incidente em Antares, de Érico Veríssimo, o modo radical com que a literatura procura criar efeitos de realidade ao expor o paradoxo que se firma com a recuperação de fatos de uma realidade historicamente datada e com um trabalho eficaz de estranhamento desses mesmos fatos. Valendo-se de estratégias que desarticulam as barreiras entre o relato de cunbo bistórico e a invenção literária, o romance explora recursos de referencialização para distender as possibilidades de os eventos serem colados a uma realidade concreta. Explora a proximidade com fatos e acontecimentos reais para compor uma magistral transgressão calcada em ilusões e na capacidade que tem a literatura de re-apresentar o real.

Palavras-chave: Incidente em Antares, Érico Veríssimo, literatura, encenação.

A relação do texto com o real (que talvez se possa definir como aquilo que o texto propõe como real, ao constituí-lo como referente situado fora de si) constrói-se de acordo com modelos discursivos e categorias intelectuais peculiares a cada situação de escrita. [...] O real, assim, adquire um novo significado: o que é real, de fato, não é (ou não é apenas) a realidade visada pelo texto, mas a própria maneira pela qual o texto a visa, na bistoricidade de sua produção e na estratégia de sua escrita.

CHARTIER, 1987 


\begin{abstract}
A obra do escritor gaúcho Érico Veríssimo tem como característica marcante a proximidade do texto com fatos acontecidos e com a intenção de ordenar os eventos de forma a propiciar a participação de personagens habilmente criadas a partir de traços e da vida de pessoas que integram a vida social. Por outro lado, o fato acontecido dissolve-se na narração de eventos ficcionalmente criados, anulando muitas vezes as possibilidades de se separarem acontecimentos concretos da realidade a que o romance dá vida.
\end{abstract}

A técnica romanesca de utilização de dados da realidade histórica foi bastante utilizada pelo romantismo brasileiro como forma de registro, pelo viés da ficção, do passado sempre apreendido a partir de "episódios que tivessem conotação épica" (ZILBERMANN, 2000, p. 33). Zilbermann ressalta aspectos da ficção de José de Alencar, vendo-os como comprovação de sugestão dada à intelectualidade brasileira pelo botânico, Karl Friedrich Philipp von Martius, no artigo "Como se deve escrever a História do Brasil", publicado em 1845, em que salienta a necessidade de a História ser escrita com um Ephos, como uma intenção épica. A visão de von Martius adequava-se bem à intenção dos românticos de criarem personagens marcados por nobre heroísmo e caráter exemplar, que se tornariam emblema do passado glorioso da nação.

Pode-se dizer que a tradição de Alencar é seguida por Érico Veríssimo, embora, em muitos romances do escritor gaúcho, o ephos esteja deslocado para o registro da história de personagens do cotidiano ou para a observação das contradições de atos e ações característicos dos segmentos sociais mais elevados. Essa tendência está presente no emaranhado de acontecimentos conclamados para registrar o longo período narrado em $O$ tempo e o vento (1949), cujos acontecimentos se estendem dos fins do século XVIII ao século XX, mais precisamente, ao ano de 1945. Sem se preocupar com o relato dos acontecimentos históricos em si, mas com a intenção de percebê-los com uma visão crítica, o ephos, em Érico Veríssimo, apresenta-se já problematizado. As diferentes junções estabelecidas no romance entre o acontecido e o inventado narram-se por uma voz que costura os fatos sem a preocupação com a fidelidade do que pode ser observado ou comprovado. A verdade do romance está construída pela capacidade do relato de encenar para os leitores uma realidade que, não sendo verdadeira, é capaz de simular uma relação possível com o referente, fazendo-se realidade, no romance, por uma "determinada escrita, por determinado modo de composição”, como afirma Michel Zéraffa (1971). 
Zéraffa, comentando uma afirmação de Michel Foucault sobre o fato de o romance moderno ter deixado de ser um monumento para se mostrar como documento, acentua o caráter paradoxal do gênero - pelo menos ao se constituir a partir de vestígios do passado - quando procura expor fatos, captados na sua mais concreta imediatez. A proximidade com o documento reforça a tensão da escrita romanesca porque a interpretação da realidade não se pode fazer sem uma reflexão estética que "corrige a dependência em relação aos ideais ou valores próprios do seu meio cultural e social de origem” (ZÉRAFFA, 1971, p. 59). A visão do teórico aproxima-se, de certa forma, da expressa por Roger Chartier (1987), no texto da epígrafe com que se inicia este texto. O autor acentua o fato de o real no texto - e o teórico está se referindo, inclusive, ao texto que se valida como documento - apresentar-se como uma construção. A literatura é livre para encenar o contexto a partir de várias visões porque o seu trabalho consiste em radicalizar sua impossibilidade de assumir um repertório factual a não ser pela exposição dos signos à vertigem dos sentidos.

No romance Incidente em Antares (1971), Érico Veríssimo explora, de forma radical, a capacidade da literatura de criar efeitos de realidade, de expor-se de forma excessivamente ilusória como realidade e valer-se de estratégias que desarticulam as barreiras entre historiografia e literatura. IA se articula a partir de recursos de referencialização que, entretanto, transgridem os limites representativos do chamado realismo histórico. Tais estratégias ficam evidentes desde o início do romance nas explicações dadas pelo narrador sobre a origem do nome da cidade, Antares, e no modo como o texto se apresenta ao leitor, invocando olhares que percebem na ficção os apelos à factualidade. O "pormenor concreto" a que alude Barthes no texto "O efeito de real” (1988) expõe-se no romance através de estratégias discursivas que legitimam uma intenção de diálogo com o contexto histórico extratextual, mas também se afasta da concretude desse lugar para reativá-lo enquanto criação, tensionando, de forma radical, a representação.

A composição do romance IA conclama diferentes gêneros textuais: o relatório e o diário de viagem compõem partes de um relato que arregimenta fatos e dados que se fazem necessários para a construção do amplo painel em que se desenvolve a história dos clãs Vacariano e Campolargo, responsáveis

1. Em vários momentos deste trabalho, o título do romance será indicado pela sigla IA. 
pela transformação da pequena cidade num feudo em que as relações de poder são exercidas com a finalidade de assegurar um poder que se estrutura em formas de paternalismo e violência. O narrador onisciente, ocupando ângulos de visão privilegiados, explora as potencialidades de sua posição para conduzir o relato com o apoio de dados importantes da história dos dois clãs, relacionando as histórias de família com a narrativa que tem a cidade como sua maior motivação. Como parte importante do enredo, o relatório "Anatomia de uma cidade gaúcha de fronteira" reforça a intenção de descrever a cidade de Antares a partir de diferentes versões. Criada no espaço romanesco como um microcosmo do Brasil, Antares oferece, pela exploração de recursos figurativos, possibilidades de se ler um contexto histórico-político que se torna fundamental para o entendimento de ações futuras, anunciadas desde o começo da narração.

A técnica de misturar inventividade com informações fornecidas pela História e com a observação constante da realidade política brasileira recupera estratégias de construção textual que já se mostravam na composição da trilogia O tempo e o vento, cujo primeiro volume, O continente, foi publicado em 1949: a exploração das relações entre o espaço público e o privado, mais concretamente entre família e Estado. E nesse sentido, como salienta Zilbermann (2000, p.34), Érico Veríssimo, em O tempo e o vento, apresenta alguns traços comuns com o mito tratado por Ésquilo, na Oréstia, que é também "uma crônica familiar", ainda que a trilogia criada por Veríssimo não possa ser considerada uma "reapropriação" da crônica da guerra de Tróia.

$\mathrm{Na}$ primeira parte do romance Incidente em Antares são privilegiados os relatos que se calcam em dados da realidade. Os fatos tomados à realidade histórica, descritos pelo narrador com uma intenção irônica, formalizam um processo narrativo que assume formas ambivalentes de narrar, uma vez que mistura dados da realidade histórica e política do Brasil com histórias inventadas. O pacto romanesco se faz com um leitor interessado em compreender fatos de uma realidade política que marca o período em que o livro foi escrito e publicado. A intenção de construir o romance com dados de uma situação político-social, além de explicitar uma visão crítica sobre os fatos arrolados, fica evidente na "Nota do Autor" que introduz o romance:

Neste romance as personagens e localidades imaginárias aparecem disfarçadas sob nomes fictícios, ao passo que as pessoas e os lugares que na realidade existem ou existiram, são designados pelos seus nomes verdadeiros" (p. 1). 
Uma intenção irônica perpassa o texto intitulado "Nota do Autor" quando se refere ao trabalho que, no romance, propõe transgredir os limites entre realidade e invenção. Ao assinalar a inventividade como um elemento forte da criação do romance, fica também registrado o fato de que a narrativa se embrenha em dados da história, em acontecimentos concretos, assumidos como recursos da produção ficcional. O jogo entre os dois pólos, factualidade e ficcionalidade, fica então declarado desde a "Nota do Autor", que assume o compromisso da ficção com a releitura de fatos da História e adverte sobre a intromissão da voz autoral no concerto de vozes que se deixam ouvir na instância narrativa. Desse modo, a relação entre ficção e História mostra-se em IA a partir da utilização de recursos narrativos que ultrapassam a mera interpretação de fatos, pois legitima o direito que tem a literatura de dar a esses fatos outros significados e de tecer com eles novos e inusitados arranjos. A ficção intenta, por esse recurso, quebrar a intenção de verdade dos eventos arrolados ainda que, ao rearranjá-los no espaço ficcional, eles não podem impedir que o leitor os assuma no campo da veracidade que se queria desestabilizar. Para intensificar desarranjos e deslocamentos, a narrativa ora deixa bem marcado o trabalho ficcional, ora manipula dados legitimados pelo discurso da História, ora exibe uma imbricação intencional dos diferentes relatos, fortalecendo uma hibridez que se anuncia ao leitor já na "Nota do Autor". Em quaisquer das opções, o eixo narrativo se estrutura a partir de acontecimentos que se dão numa sexta-feira 13, do ano de 1963, anunciada pelo narrador na p.2 e reiterada em diversos momentos na primeira parte do romance, o que faz com que essa parte, embora evidencie uma relação mais intensa com o factual, funcione como uma preparação para a excepcionalidade dos acontecimentos que se anunciam com a intenção de prender a atenção do leitor.

Este recurso de produção textual que ora mistura os relatos, ora parece deixá-los bem distintos, aprisiona o leitor com informações sobre os antecedentes "históricos" do incidente e com a indicação do caráter "insólito" e "tétrico" de um acontecimento que lhe será revelado apenas na segunda parte do romance. A técnica de suspense, a intenção irônica do narrador e a conclamação de recursos cênicos que se espalham pelo texto afirmam o estatuto da literatura, ainda que os dados referenciais sejam o suporte com que ela se constrói. Antares é mencionada, no capítulo I, como o teatro, o palco e o cenário dos acontecimentos que se dão no dia 13 de dezembro de 1963. Essas imagens reforçam o caráter de representação não apenas do incidente mas da própria narrativa e indicam a impossibilidade de alocação de sentidos fixos, ainda que as relações com o referente sejam demarcadas. 
O recurso da referencialização funciona com intenção oposta: o que está legitimado como verdade pelo discurso da História está sendo questionado e deslocado para um outro campo de significações. A linearidade, na narração dos eventos, é estratégia eficaz para que os acontecimentos do dia 13 de dezembro de 1964 possam ser vistos como ruptura, como intromissão do excepcional.

Na segunda parte do romance, a descrição do incidente focaliza os sete mortos que não puderam ser enterrados por causa de uma greve geral que impossibilitou o funcionamento da cidade. A volta desses sete mortos à vida possibilita a produção de novos sentidos que tensionam mais intensamente os dados fornecidos pela longa primeira parte nos quais se incluem recursos da narrativa mítica que são costurados ao relato de inspiração factual para formalizar uma proposta de construção romanesca. $\mathrm{O}$ incidente mostra-se a parte mais importante do romance porque nele se aprimoram os mecanismos de deslocamento e condensação e porque nele se acentuam particularidades do jogo ilusório que a narrativa concretiza, quando parece reverter a linearidade característica da primeira parte.

É importante observar que a reivindicação dos mortos, na segunda parte do romance, não se configura como um movimento coletivo. A decisão tomada por eles, ao se levantarem dos caixões, não seria a de usar a palavra para reivindicar a mudança da ordem social a que pertenceram, mas exporemse, em imobilidade e em silêncio, como partes de um "inconveniente do ponto de vista higiênico e estético" (p. 250). A invasão da cidade pelos mortos tem, portanto, uma função desagregadora, pois a eles só interessa pressionar a sociedade antarense para que os direitos assegurados pela morte fossem cumpridos. As cenas que os mortos aos poucos vão compondo como "um teatro de horror" permitem que outros sentidos possam ser produzidos pelo incidente quando é percebido na relação que tem com os eventos narrados na primeira parte do romance e com os introduzidos para acentuar as estratégias de apagamento acionadas pela sociedade para impedir que o fato fizesse parte de sua história. Na descrição do incidente, as manifestações bastante críticas da instância autoral acentuam a parcialidade de interpretação de pontos de vista produzidos pelo discurso da História, deixando clara a intenção de reavivar o que deve ser lembrado e apagar os detalhes que possam perturbar a ordem a ser mantida.

De certo forma, instala-se com o incidente o paradoxo entre a falta de vontade de lembrar e o interesse por avivar lembranças arquivadas na memória 
da sociedade. As relações entre memória e esquecimento são ativadas em todo o episódio do levante dos mortos constituindo-se em um eixo que faz com que a narrativa, ao mesmo tempo em que assume um caráter de denúncia, congregue recursos que podem ser explicados pelo viés do fantástico. De algum modo aguçamse instrumentos que permitem que o recalcado surja no discurso, embora possa também ser desviado para que esse sentido seja relativizado. Por outro lado, se se fortalecem as marcas do fantástico, reforça-se um clima de excepcionalidade que soterra outros sentidos que o episódio quer explicitar. Convém, por isso, investigar algumas das estratégias narrativas que garantem ao texto de Veríssimo a demarcação campos de significações que se constroem próximos à rememoração, mas ao mesmo tempo deslocam os sentidos produzidos, para permitir que o inusitado se mostre através de uma gama de significados que tensiona o lugar que o episódio ocupa no plano do romance.

É importante ressaltar o fato de o romance tornar evidentes, na construção do incidente, recursos da narrativa fantástica e de procurar, por esse recurso, inviabilizar a linearidade que o episódio dos mortos parece subverter. Nesse sentido aos recursos que estruturam a diegese parecem querer privilegiar duas direções de leitura: uma reforça a ilusão de realidade que predomina por toda a primeira parte do livro; outra a faz contrapor-se aos fatídicos acontecimentos do dia 13 de dezembro de 1963. Fica claro, todavia, que, embora o romance adote estratégias narrativas do fantástico, não é sua intenção narrar uma estória de fantasmas. O intuito é bem outro e revela-se através de determinadas estratégias que o incidente exibe.

Ao focalizar a atenção do leitor nos arranjos que culminam com a saída dos mortos de seus caixões para assumirem, em conjunto, uma ação reivindicativa a partir da exposição de seus corpos em decomposição, a narrativa acentua recursos próprios ao fantástico. Não permite, no entanto, que a exibição que transforma os mortos e os habitantes de Antares em atores de uma fantástica peça que apresenta contra-discursos e falas inusitadas, destoe do propósito de acentuar uma intenção desconstrutora, que se manifesta na presença dos mortos na cidade e na exposição, em praça pública, das mazelas que contaminam a cidade.

$\mathrm{Na}$ montagem desse espetáculo, os mortos ocupam vários lugares - o cemitério, a rua, a praça - exibindo sempre uma ruptura na estabilidade narrativa. Funcionando como desarticulação de previsibilidades, os mortos forçam a releitura do que já fora narrado e dão maior visibilidade aos espaços 
marcados pela exclusão ou pela eficácia do autoritarismo que emblematiza as várias ordens - histórica, política, social - que os eventos da primeira parte do romance narram de forma linear. Ao trilharem uma via que se desenvolve no avesso da ordem estabelecida, os insepultos exibem situações recalcadas, escancarando as portas do "real", ainda que o episódio se aproprie de recursos próprios da narrativa fantástica. As estratégias de inversão e ruptura desarticulam sentidos previsíveis e expõem possibilidades de se exibirem o reverso da normalidade ameaçada.

Mostrando-se em uma via de mão dupla, a situação inusitada transgride as barreiras do possível, mas, paradoxalmente, amplia as possibilidades de se enxergar o mundo a partir de outros ângulos de visão. Por esse motivo, os lugares ocupados pelos mortos insepultos assumem na narrativa significados que extrapolam os permitidos pelo senso comum. O cemitério deixa de ser o campo do descanso eterno e assume um tipo de vitalidade que lhe é interditado. Os mortos, embora pertencendo a um outro plano, falam, andam, debocham uns dos outros e voltam aos lugares que, quando vivos, ocupavam na sociedade: os de maior prestígio assumem o discurso reivindicativo e determinam o que deve ser feito; os excluídos obedecem e silenciam-se. Assim, quando os mortos decidem descer à cidade para reclamar o direito de serem enterrados, o grupo se organiza de acordo com o status do morto. D. Quitéria Campolargo fica à frente de todos e o Dr Cícero Branco "marcha um passo atrás dela" (p. 255). Erotildes, a prostituta, e Pudim de Cachaça, excluídos em vida, "deixam-se ficar naturalmente para trás" (p. 255) nessa nova ordem que, em tudo, recupera os lugares socialmente demarcados.

É de se notar que, embora a transgressão operada pelo fantástico indique rupturas e possibilite alterações no mundo da realidade encenada, o episódio dos mortos insiste na produção de efeitos de realidade que fortalecem a tendência clara de Incidente em Antares se construir como uma literatura testemunhal. Nesse sentido, é de se considerar que o fantástico impõe uma ruptura na linearidade narrativa, mas, ao mesmo tempo, reitera uma intenção documental. Por esse motivo, pode-se dizer que o fantástico transgride o seu próprio discurso já que visa a intensificar as possibilidades de a literatura induzir a ligações com o mundo extra-ficcional. O fantástico mostra-se então como mais uma possibilidade do texto de, através de diferentes transgressões, vasculhar os dados que se constroem com as junções possíveis entre fato, documento, testemunho e o modo como esse material é apresentado no cenário da literatura. 
O caráter realista da narrativa fica assim acentuado na exploração de recursos que, conforme se salientou em outro momento, estão indicados no conto "Gênesis" do autor de IA, intensificando as relações entre fantástico e alucinação, mas também as possibilidades de esses recursos possibilitarem ler a realidade com olhos menos controlados (FONSECA, 1980, p. 75).

O levante dos mortos impõe uma anormalidade que também se mostra no modo como eles se inserem no mundo dos vivos. Os mortos ressuscitam, embora não deixem de apresentar marcas da situação de "não vivos" em que estão: seus corpos continuam a apodrecer, exalam um cheiro fétido, característico da decomposição. Ao mesmo tempo, pensam e falam como se continuassem vivos. E mais ainda, têm condição de analisar os fatos que explicam a sua vida e a da sociedade a que pertenceram. Por isso, o fantástico assume, no episódio, tanto a transgressão dos "postulados hipotéticos agenciados pela literatura" (TODOROV, 1975, p. 14), quanto a irrupção do inadmissível no seio da inalterável legalidade cotidiana (CAILLOIS, 1965, p. 161).

Note-se que, quando os mortos se levantam dos caixões, no cemitério, as barreiras que os mantinham separados, em vida, imediatamente se recompõem. Ou melhor, mesmo antes de os mortos assumirem-se como vivos, as barreiras estavam demarcadas pelo tipo de caixão em que são colocados e pelo tipo de velório que cada um teve. No cemitério, o narrador, embora assuma elementos próprios à descrição da ambigüidade da situação, não deixa de assinalar que os privilégios de classes continuam a existir entre os mortos. Não é por acaso que, insistindo no inusitado da situação que propicia aos mortos voltarem à vida, a fala do narrador é sempre muito crítica com relação à inversão produzida pelos recursos que o romance agencia. Em virtude do agenciamento de diferentes recursos discursivos, o levante dos mortos precisa ser considerado não apenas como inversão e nem somente como continuidade dos eventos que se vinham narrando. A sua compreensão agencia significados que se produzem nas inter-relações entre uma situação e outra. A ruptura é assinalada com o inusitado da situação, mas tão logo ela se concretiza, os valores e as idéias vigentes no mundo fora do cemitério continuam a vigorar. Ironicamente o narrador desmente a frase de efeito emitida pela matriarca dos Campolargos, D. Quita, quando afirma que a morte nivela a todos e por isso apaga os vestígios de classe, e torna evidentes os contratos que se estabelecem entre os mortos para garantir as possibilidades de se alcançarem os fins que defendem. 
Por isso o apelo ao fantástico se dá mediado pela intenção de denúncia e de crítica que caracteriza a performance do narrador. Esse modo de narrar, sempre permeado por uma intenção irônica, está presente de forma mais amena na primeira parte do romance e intencionalmente escancarada no episódio do levante dos mortos. Na descida dos mortos à cidade, a intenção irônica, presente na voz narrativa, ressalta as diferenças sociais que o cortejo inusitado expõe e o espanto dos habitantes diante do espetáculo de horror. As mediações propiciadas pelo fantástico aceleram a exibição de "extremos de concretude do signo que se expõe até o limite de sua representalbilidade" (SHOLLHAMMER, 2002, p. 76), ainda que tudo se apresente ao leitor como deslocamento, ruptura, desequilíbrio. Pode-se dizer que o episódio trabalha com uma estratégia que tanto aponta para o desmanche de dados da realidade, quanto fortalece a sua reconfiguração.

Por isso a exposição dos mortos - particularmente na descida à cidade - concretiza a certeza do desaparecimento de possibilidades de entendimento do que se mostra como "uma outra realidade". Essa, exibindo-se em diferença, rearticula as possibilidades de acesso à realidade encenada pelo texto. Assim, o desequilíbrio que se instala na narrativa só se dá sob alguns aspectos, porque, embora pareça deslocar os eventos da linearidade característica da primeira parte do romance, ajuda a unir, com pontos dados em uma outra ordem, os acontecimentos inusitados de que participam os mortos e os eventos que se relatam após o encerramento do enfrentamento acontecido no coreto da cidade de Antares.

O levante dos mortos precisa então ser considerado sempre na oscilação entre pontos demarcados. Se como excepcionalidade delineia um outro espaço em que as separações entre morte e vida ficam abaladas, não impede a restauração do cenário de desordem que os mortos compõem. E, se os espaços ocupados por mortos e vivos ficam bem delineados - a cidade, espaço dos vivos, contrapõe-se ao cemitério, espaço dos mortos - essa mesma separação ajuda a articular um outro lugar, porque os mortos insepultos não pertencem, no momento do levante, a nenhum dos espaços em oposição e, por isso, ficam "fora da lei", como transgressão de uma e outra ordem. A questão espacial é por isso fundamental para se compreender o modo como o levante dos mortos se estrutura como transgressão. A observação de Lefebvre (1976) é importante para se perceber a noção dos espaços socialmente organizados, de que a cidade e o cemitério são emblemas, e o espaço de exceção, marcado pelo inusitado do levante dos mortos. Diz Lefebvre, citado por Soja (1993, p. 102): 
O espaço não é um objeto científico afastado da ideologia e da política; sempre foi político e estratégico. (...) O espaço sempre foi formado e moldado a partir de elementos históricos e naturais, mas esse foi um processo político. O espaço é político e ideológico. É um produto literalmente repleto de ideologias.

A observação de Lefebvre salienta que a configuração espacial, embora de natureza física, não exclui os componentes políticos e ideológicos que determinam sua forma de ser. O espaço é aquilo que a ideologia constrói a partir de referências que extrapolam as características físicas do lugar. Considerando essas características espaciais, podemos dizer que os mortos insepultos tanto descaracterizam os espaços da cidade e do cemitério, quanto reforçam as suas configurações. Não pertencendo mais à cidade e tendo optado por abandonar o cemitério, os mortos delimitam um outro espaço, o dos mortosvivos, um espaço de exceção em que as leis da cidade e as do cemitério são temporariamente franqueadas, embora não abolidas. Por isso o espaço de exceção, o espaço dos mortos-vivos, que o romance legitima pelo viés do fantástico, não anula as amarras que estabelece com a cidade e o cemitério. $O$ espaço dos mortos vivos é, como se afirmou em outro momento (FONSECA, 1980), um lugar gerador de ambivalências.

Esse lugar se configura pelas leis apontadas por Mikhail Bakhtine (1970) como próprias de um processo que ele denomina de intronização/ desintronização. Tal processo, classificado pelo teórico russo através de suas profundas ambivalências, pela capacidade de conter, ao mesmo tempo, "dois elementos em um", permite que leiamos o levante dos mortos, no romance de Érico Veríssimo, como um processo de intronização que traz consigo, inexoravelmente, as marcas da desintronização.

Os mortos, ao voltarem à vida, ainda que por um breve período, têm um objetivo concreto, o de serem "sepultados dignamente" (p. 249). Inseremse, por isso, num processo de intronização que, como salienta Bakhtine, já anuncia a desintronização, uma vez que só querem que lhes seja garantido o direito que têm de serem enterrados. Por outro lado, ao se apresentarem aos vivos com a mortalha da morte, os insepultos explicitam o caráter temporário da intronização, porque exibem a impossibilidade de se fixarem no espaço dos vivos. O apelo ao fantástico é por isso um recurso hábil para demonstrar a instabilidade do lugar ocupado pelos mortos. Manifestando-se em situações de 
exclusão que só podem ser significadas com relação a uma ordem considerada estável, o fantástico define-se por uma irredutível impressão de estranheza fadada a desvanecer para que o equilíbrio suspenso seja retomado.

Mas a desordem introduzida pelo fantástico pode ser um instrumento eficaz para que se aponte a precariedade daquilo que é considerado estável. A estabilidade, ao ser suspensa pela intromissão do fantástico, não poderá ser retomada sem apresentar rachaduras, vestígios do que aconteceu, ainda que, na superfície das coisas, a normalidade se estabeleça. A mesma desestabilização é provocada pela decisão dos mortos de entrar novamente na cidade e enfrentar os motivos que impedem que lhes seja dado o enterro a que têm direito. Assim, instaurando um desequilíbrio, os mortos-vivos irão provocar uma outra fissura que expõe as mazelas da sociedade mas que, ao mesmo tempo, desloca o sentido de transgressão que o levante produz.

É de se considerar ainda que, ao se exibirem aos vivos como mortos, ou melhor, como mortos-vivos, os insepultos transgridem tanto a ordem dos habitantes de Antares quanto a daqueles que jazem no cemitério. Essa transgressão, todavia, não se faz em favor de uma causa que indique uma verdadeira revolução na ordem da cidade. Tanto é assim que os mortos não se mostram solidários com os operários em greve que também efetuam um desequilíbrio, uma suspensão da normalidade. A radicalização do movimento operário em virtude da atitude dos patrões em não cederem às pressões dos explorados leva ao fechamento do cemitério. Esse fato impede o sepultamento dos sete mortos que, ao exigirem o cumprimento do direito de serem enterrados, formalizam uma forma de greve que não endossa a dos operários. Os mortos exigem dos vivos o direito de serem enterrados a qualquer preço, dentro do prazo estipulado por eles: vinte e quatro horas. Reafirma-se, por esse propósito, a relação vista por Bakhtine entre intronização e desintronização: o empecilho causado pelos mortos exige que a cidade force a volta à normalidade e, desse modo, a ruptura provocada pelos insepultos já anuncia o seu próprio desmanche como também desestabiliza o outro desequilíbrio, o obrigando o fim da greve dos operários.

No entanto, porque subvertem a normalidade e introduzem uma descontinuidade, é possível também perceber o movimento dos mortos como extensão da greve dos operários e o julgamento dos vivos - que se inicia ao meio-dia do dia 13 de dezembro - como um diagnóstico das doenças morais e sociais que alojam no corpo da cidade. Todavia, a proximidade 
entre o movimento dos operários e o dos mortos é , nesse sentido, apenas acidental, pois os dois grupos fazem diferentes reivindicações. E, como se vem demonstrando, se os interesses dos dois grupos se aproximam em determinado momento - porque a tensão que os configura advém da ruptura do equilíbrio da normalidade -, em outro momento a separação entre as duas formas de reivindicação fica assegurada.

A intenção de vincular a insurreição dos defuntos à dos trabalhadores está apenas em Barcelona, o sapateiro, que representa a classe dos trabalhadores e em João Paz, o torturado pela polícia política até à morte, em virtude de sua adesão às idéias revolucionárias. Os demais defuntos, principalmente D. Quitéria Campolargo, que pertencera à alta burguesia antarense, e Cícero Branco, que nada fez enquanto vivo que defender os direitos da classe burguesa, permanecem como sempre foram. Mesmo como morto essa proximidade entre ele e a burguesia antarense continua marcada em sua fala: "Pois, amigos, aqui temos conosco D. Quitéria Campolargo, uma das mais ilustres, senão a mais ilustre, da sociedade de Antares" (p. 239). Embora, como morto-vivo, Cícero Branco seja o advogado dos sete falecidos, em nenhum momento ele defende o movimento dos operários em greve. O mesmo acontece com o pianista suicida, Menandro Olinda, que mantém como morto a indiferença com relação aos problemas coletivos já que só se lembra dos tormentos que impediram a sua carreira de artista. Os demais, "gentinha sem importância”, como os define o advogado Cícero Branco, não podem defender os seus princípios porque estão representados pelo advogado que fala por eles. Não é, portanto, por acaso, que, ao descerem pela rua Voluntários da Pátria, em direção ao centro da cidade, seja respeitada uma hierarquização que mimetiza os lugares ocupados por cada um na sociedade antarense.

Ao se horrorizarem com o desfile dos mortos, os habitantes de Antares assistem, como num teatro, à encenação de "uma espacialização societária complexa e cheia de contradições" (SOJA, 1993, p. 127). Os habitantes de Antares acompanham a encenação das contradições da cidade, mas não conseguem percebê-las em maior profundidade. Por isso, porque desejam se livrar dos incômodos provocados pelos insepultos, acabam por reforçar a visão de que a greve dos operários é a única culpada pelo transtorno sofrido pela cidade.

Temos ressaltado o fato de os mortos ocuparem um lugar provisório de que a decomposição de seus corpos é um índice significativo e o desequilíbrio criado por eles mostrar-se por isso como passageiro. Embora esse desequilíbrio acelere os conflitos que se mostram no "espetáculos dos mortos", também assegura a continuidade do equilíbrio; em suma, a ressurreição dos mortos é um 
acontecimento que já traz consigo as marcas de sua curta duração. Ao exporem em seus corpos os signos "podres" da decomposição, garantem a necessidade de que sejam expulsos da cidade ou que voltem a habitar o espaço onde devem ficar confinados. Por tais motivos, como se vem demonstrando, a revolta dos mortos deve ser interpretada a partir das várias significações que possibilita construir. Se se pode percebê-la, como o fizeram alguns antarenses, como "uma greve dentro da greve", expõe também uma grande diferença com relação ao movimento iniciado pelos operários. Aproxima desse movimento, porque fratura a ordem dos acontecimentos considerados normais, mas distancia-se dele, porque as reivindicações dos mortos não fortalecem a ruptura provocada pelos operároios; pelo contrário, enfraquecem-no já que exigem a volta da cidade à normalidade.

Fernando Catroga (2001), retomando observação de Oliveira Martins, considera o papel importante que os mortos desempenham na escrita da História. Os cemitérios, assim como a escrita, diz ele, são re-presentificações de algo do que já se sabe não existir. Na opinião do historiador, a escrita da História exorciza a morte, "introduzindo-a no discurso, para criar, como no jogo simulador e dissimulador do culto evocativo dos mortos, a ilusão da sua existência" (p. 55). Todavia a morte culturalmente legitimada está em oposição à vida e só pode ser evocada a partir da interrogação de indícios e traços que configuram o processo de "re-presentificação". A visão do historiador possibilita registrar, como se vem fazendo, a ruptura causada pelo levante dos mortos, mas também legitima a conjunção de "indícios e traços" que configurariam a "re-presentificação" de algo que já se sabe não existir. Os mortos-vivos só podem ser considerados a partir de um espaço em que o espanto e o horror instalam uma quebra, uma suspensão de limites que não pode ser duradora porque significaria a reversão de estratégias que a narrativa agencia para cunhar sentidos sempre ambivalentes. Os mortos-vivos revolvem situações e acontecimentos controlados por normas de convivência, mas, porque se colocam em situação de exceção, acirram formas de controle que a ordem consagra. Por essas razões, o cortejo dos mortos produz re-presentificações não apenas de algo que se sabe não existir, mas também de sentidos que se ligam a representações de "parada militar" e de "bloco carnavalesco".

Tanto os lugares ocupados no "desfile" dos mortos na descida à cidade, quanto as vestimentas usadas por eles agregam sentidos que transitam entre o que pode estar contido nos significantes "farda" e "fantasia", entre ordem e desordem, mas que também extravasam desses lugares, não se fixando, por isso, em nenhum dos campos de significação porque indicam incessantemente 
a intenção de que os termos sejam percebidos através das possibilidades que têm de se situarem num campo e noutro (FONSECA, 1980). Por esse movimento de constante oscilação - os mortos-vivos reivindicam um estatuto de morto, mas agem como se vivos estivessem - os insepultos participam, também em oscilação, de um desfile militar ("Pois é, amigos e romanos, desçamos sobre Antares, convida o advogado. Proponho que D. Quitéria Campolargo abra a marcha"- p. 254) ou integram um bloco carnavalesco ("Ué, bloco de carnaval em dezembro?" - p. 256), consagrando uma situação de exceção que desestabiliza hierarquias ao mesmo tempo em que as exibe, sempre em tensão.

Num movimento que remete à função das testemunhas num tribunal, mas que também insere o que pode ser dito por elas num jogo em que a comprovação do delito está sempre mediada pelo fato de que tudo é mostrado como num espetáculo, o romance Incidente em Antares elabora, no plano da ficção, "uma interpretação e um sentido de um passado de outra forma irrecuperável" (CATROGA, 2001, p. 73). As "memórias subterrâneas" que, conforme Pollak (1989, p.4) "afloram em momentos de crise em sobressaltos bruscos e exacerbados", emergem para se exporem junto com o reacionarismo característico das classes altas. Por isso, a ruptura, transformada em espetáculo, é provisória, temporária, mas, ainda que se mostre claramente como teatro e reforce estratégias de ficcionalidade, possibilita que seja visto, no curto espaço em que dura a encenação, o que está sendo gestado nos subterrâneos da sociedade. As intensas contradições da sociedade antarense alcançam múltiplas significações produzidas por movimentos que distendem as possibilidades de produção de efeitos de sentidos, que fazem da cidade metonímia da sociedade brasileira, e legitimam, pelos recursos ficcionais acionados, a expansão da escrita literária para o contexto de sua produção. A força das palavras dos mortos-vivos encena uma possibilidade de o testemunho poder comprovar a veracidade de atos e fatos ainda que a vitalidade das acusações e das palavras "podres", no sentido literal e metafórico, ditas por eles no coreto, se apresente sempre esvaziada pela própria inviabilidade de o testemunho conseguir abarcar inteiramente os sentidos produzidos pelo fato e pelo acontecimento.

De certo modo, o testemunho dos mortos traz à tona uma outra possibilidade de entendimento do acontecido. Embora cada morto-vivo, ao resgatar "histórias de vida" e dados da realidade social, repise as causas que impedem o seu sepultamento, o seu testemunho traz à tona tanto os atos dos que ficaram como herdeiros dos mortos de "classe alta", quanto episódios de histórias 
silenciadas que compõem as "memórias subterrâneas", de que fala Michel Pollak (1989). É, portanto, através de uma situação de excepcionalidade, que os mortos conseguem invadir o espaço público e exporem as lembranças traumatizantes confinadas ao silêncio: a tortura política, as mazelas concretizadas pela miséria e prostituição, a corrupção como um dado comum entre os poderosos.

O espetáculo dos mortos ganha, assim, uma dimensão ampla no romance que, construindo-se muito próximo ao relato da História, deste se descola quando propõe recontar o que já fora dito por um outro viés possibilitado pela literatura. Assim, quer se analise o episódio do levante dos mortos como "episódio fantástico", quer seja visto através do que Mikail Bakhtin consagrou como carnavalização, o mais importante, parece-nos, é compreender os recursos literários postos em prática em sua construção para possibilitar um trabalho que expõe o paradoxo, que se afirma pela necessidade de dizer e representar, de afirmar uma indizibilidade e uma irrepresentabilidade, que é próprio da literatura.

Problematizando feições do discurso testemunhal e possibilidades de resgate do acontecido, o romance Incidente em Antares se constrói assumindo os paradoxos que nele se explicitam. Como os mortos-vivos que ocupam um espaço em que a transitoriedade expõe-se sem cessar, o romance ressalta a tentativa de a literatura - que ocupou com freqüência o lugar do testemunho no contexto de produção do romance Incidente em Antares - conviver com a impossibilidade de representar e testemunhar experiências e de se mostrar sempre como um processo de produção de sentidos que não pode impedir, entretanto, que o que é dito, no espaço romanesco, não possa ser tomado pelo leitor como um testemunho.

Abstract: The article intends to focus on, in the novel Incident in Antares, by Érico Verissimo, the radical manner in which literature seeks to create reality effects by exposing the paradox that firms itself by recovering facts from a bistorically dated reality and with an effective work of alienating those same facts. By using strategies that disarticulate the barriers between the bistorically featured report and literary fiction, the novel employs referring resources to distend the possibilities that the events are linked to a concrete reality. It looks into the proximity with facts and real events to compose a superior transgression treaded in illusions and in the ability that literature has of reintroducing what is real.

Key words: Incident in Antares, Érico Veríssimo, literature, staging. 
Disponivel em: http://www.letras.ufmg.br/poslit

Referências Bibliográficas

BARTHES, Roland. O efeito de real. In: O rumor da língua. Trad. Mário Laranjeira. São Paulo: Brasiliense: 1988, p. 158-165.

BAKHTINE, Mikhail. La poétique de Dostoieusky. Trad. Isabelle Kolitcheff. Paris: Seuil, 1970.

CHARTIER, Roger. Intellectual history or sociocultural history? In: LA CAPRA, Dominique; KAPLAN, Steve L. (Org.). Modern European intellectual history: reappraisals and new perspectives. Itaca/London: Cornell U.O., 1987, p. 13-44.

FONSECA, Maria Nazareth Soares. A relação Historia/estória em Incidente em Antares. Belo Horizonte: FALE/UFMG, 1980 (dissertação de Mestrado - texto inédito).

CAILLOIS, Roger. Au coeur du fantastique. Paris: Gallimard, 1965.

CATROGA, Fernando. Memória e História. In: PESAVENTO, Sandra Jatahy. Fronteiras do milênio. Porto Alegre: Editora Universidade/UFRGS, 2001. p. 43-69.

LEFEBVRE, H. Reflections on the Politics of Space. Trad. M. Endres, Antipode, 8, 1976, p. 30-37.

SCHOLLHAMMER, Karl Erik. À procura de um novo realismo: teses sobre a realidade em texto e imagem de hoje. In: OLINTO, Heidrun Krieger; SCHOLLHAMMER, Karl Erik. Literatura e Mídia. Rio de Janeiro: Editora PUC Rio/Edições Loyola, 2002. p. 76-90.

SOJA, Edward S. Geografiaspós-modernas: a reafirmação do espaço na teoria social crítica. Trad. Vera Ribeiro. Rio de Janeiro: Jorge Zahar Ed. 1993.

TODOROV, Tzvetan. Introdução à literatura fantástica. Trad. Maria Clara Corrêa Castello. São Paulo: Perspectiva, 1975.

VECCHI, Roberto. Barbárie e representação: o silêncio da testemunha. In: PESAVENTO, Sandra Jatahy. Fronteiras do milênio. Porto Alegre: Editora Universidade/UFRGS, 2001. p. $71-94$.

VERÍSSIMO, Érico. O Continente. Tomo I. Porto Alegre: Globo, 1978.

VERÍSSIMO, Érico. Incidente em Antares. Porto Alegre: Globo, 1971.

ZILBERMANN, Regina. Saga familiar e história política. In: GONÇALVES, Robson Pereira (Org.). O tempo e o vento: 50 anos. Bauru/SP/EDUSC, 2000. p. 25-42. 